\title{
PEMBERDAYAAN KOLABORASI UAD DAN MUHAMMADIYAH DI BOJONEGORO
}

\author{
Oleh: Muhammad Aziz \\ Ringkasan
}

Tujuan diselenggarakannya KKN PPuN Universitas Ahmad Dahlan adalah KKN PPuN dilaksanakan dalam rangka kerjasama dengan Lembaga Seni Budaya dan Olahraga Pimpinan Pusat Muhammadiyah (ditempatkan di Kabupaten Karawang dan Kota Tasikmalaya, Provinsi Jawa Barat; Kota Pekalongan dan Kabupaten Kebumen, Provinsi Jawa Tengah; dan Kota Madiun dan Kabupaten Bojonegoro, Provinsi Jawa Timur).

Kata Kunci: Pemberdayaan, Kolaborasi, Muhammadiyah

\begin{abstract}
Abstrak
The objective of the KKN PPuN program of Ahmad Dahlan University is KKN PPuN is conducted in cooperation with the Arts and Culture Institute of Muhammadiyah Central Executive (placed in Karawang and Tasikmalaya, West Java Province, Pekalongan City and Kebumen Regency, Central Java Province and Madiun City and Bojonegoro Regency, East Java Province).
\end{abstract}

Keywords: Empowerment, Collaboration, Muhammadiyah

\section{A. PENDAhUluan}

Kuliah Kerja Nyata (KKN) muncul dari konsep atas kesadaran mahasiswa sebagai calon sarjana untuk dapat memanfaatkan sebagian waktu belajarnya menyumbangkan pengetahuan dan ilmu yang telah diperolehnya secara langsung dalam membantu memecahkan dan melaksanakan pembangunan di dalam kehidupan masyarakat. Dari berbagai pengalaman menunjukkan bahwa peranan mahasiswa dalam berbagai kegiatan telah memberikan bukti-bukti serta memperkaya akan arti dan peran mahasiswa sebagai tenaga kerja terdidik dalam berbagai aspek kegiatan pembangunan.

KKN bagi mahasiswa diharapkan dapat menjadi suatu pengalaman belajar yang baru untuk menambah pengetahuan, kemampuan dan kesadaran hidup bermasyarakat. Bagi masyarakat kehadiran mahasiswa diharapkan mampu memberikan motivasi dan inovasi dalam bidang sosial kemasyarakatan. Hal ini selaras dengan fungsi perguruantinggi sebagai jembatan komunikasi dalam proses pembangunan dan penerapan IPTEK pada khususnya.

Tujuan utama dari kuliah kerja nyata adalah memacu pembangunan masyarakat dengan menumbuhkan motivasi kekuatan sendiri dan mempersiapkan kader-kader pembangunan stock holder serta sebagai agen perubah (agen of change). Tujuan utama lainnya adalah agar mahasiswa memperoleh pengalaman belajar yang berharga melalui.

\section{B. KERANGKA TEORI}

\section{Definisi KKN}

Kuliah Kerja Nyata (KKN) adalah bentuk kegiatan pengabdian kepada masyarakat oleh mahasiswa dengan pendekatan lintas keilmuan dan sektoral pada waktu dan daerah tertentu. Pelaksanaan kegiatan KKN biasanya berlangsung antara satu sampai dua bulan 
dan bertempat di daerah setingkat desa. Direktorat Jenderal Pendidikan Tinggi di Indonesia telah mewajibkan setiap perguruan tinggi untuk melaksanakan KKN sebagai kegiatan intrakurikuler yang memadukan tri dharma perguruan tinggi yaitu: pendidikan, penelitian, dan pengabdian kepada masyarakat.

Pada tahun 1971 Direktur Pendidikan Tinggi Departemen Pendidikan dan Kebudayaan menetapkan tiga universitas yaitu Universitas Andalas di bagian barat, Universitas Gadjah Mada di bagian tengah, dan Universitas Hasanuddin di bagian timur, sebagai perintis proyek kegiatan pengabdian masyarakat. Proyek perintis ini dikenal dengan nama Pengabdian Mahasiswa kepada Masyarakat. Hasil laporan dan evaluasi dari ketiga perguruan tinggi perintis proyek ini dipaparkan pada Rapat Rektor Universitas atau Institut Negeri pada bulan Maret 1972, setelah selesai rapat tersebut Direktur Pendidikan Tinggi meminta 13 Universitas di 13 provinsi untuk melaksanakan proyek perintis kuliah kerja nyata pada tahun ajaran 1973-1974.

Universitas Gadjah Mada bertindak sebagai universitas pembina, sedangkan dua belas universitas lainnya termasuk kategori universitas madya, keduabelas universitas tersebut adalah: Universitas Syiah Kuala, Universitas Sumatera Utara, Universitas Andalas, Universitas Sriwijaya, Universitas Padjajaran, Universitas Diponegoro, Universitas Brawijaya, Universitas Udayana, Universitas Lambung Mangkurat, Universitas Hasanuddin, Universitas Sam Ratulangi, dan Universitas Pattimura. Pada awal perkembangannya, KKN hanya merupakan paduan dari dua dharma yaitu pengajaran dan pengabdian masyarakat, seiring perkembangannya kkn juga meliputi dharma penelitian. Perpaduan tri dharma perguruan tinggi pada mewujudkan KKN sebagai salah satu subsistem pendidikan tinggi di Indonesia.

\section{Tujuan KKN}

Mahasiswa dapat mengembangkan pemikiran berdasarkan ilmu tekhnologi dan dalam upaya menumbuhkan, mempercepat serta mempersiapkan kader-kader pembangunan. Mahasiswa memperoleh pengalaman belajar yang berharga melalui keterlibatan dalam masyarakat yang secara langsung menemukan, merumuskan, memecahkan dan menanggulangi permasalahan pembangunan secara prakmatis dan interdisipliner. Untuk menambah wawasan Mahasiswa memotivasi masyarakat dalam membangun Desa.

Untuk memberikan pengalaman kepada mahasiswa tentang cara-cara dalam bermasyarakat. Adanya Kuliah Kerja Nyata mempunyai sasaran agar mahasiswa dapat menjadi generasi yang siap pakai dan sekaligus calon penerus pembangunan utamanya di daerah pedesaan, baik dimasa sekarang maupun dimasa yang akan datang. 
Diterbitkan oleh Lembaga Pengabdian kepada Masyarakat

Universitas Ahmad Dahlan Yogyakarta

\section{Definisi Kota Madiun}

Kota Madiun adalah sebuah kota di Provinsi Jawa Timur, Indonesia. Kota ini terletak $160 \mathrm{~km}$ sebelah barat Surabaya, atau $111 \mathrm{~km}$ sebelah timur Surakarta, Jawa Tengah. Di kota ini terdapat pusat industri kereta api (INKA). Madiun dikenal memiliki Lapangan Terbang Iswahyudi, yakni salah satu pangkalan utama AURI, meski sebenarnya terletak di Kabupaten Magetan. Madiun memiliki julukan Kota Gadis, Kota Brem, Kota Pelajar, Kota Sepur, Kota Pecel, Kota Budaya, Kota Sastra, dan Kota Industri.

Madiun merupakan suatu wilayah yang dirintis oleh Ki Panembahan Ronggo Jumeno atau biasa disebut Ki Ageng Ronggo. Asal kata Madiun dapat diartikan dari kata "medi" (hantu) dan "ayun-ayun" (berayunan), maksudnya adalah bahwa ketika Ronggo Jumeno melakukan "Babat tanah Madiun" terjadi banyak hantu yang berkeliaran. Penjelasan kedua karena nama keris yang dimiliki oleh Ronggo Jumeno bernama keris Tundhung Medhiun. Pada mulanya bukan dinamakan Madiun, tetapi Wonoasri.

Sejak awal Madiun merupakan sebuah wilayah di bawah kekuasaan Kesultanan Mataram. Dalam perjalanan sejarah Mataram, Madiun memang sangat strategis mengingat wilayahnya terletak di tengah-tengah perbatasan dengan Kerajaan Kadiri (Daha). Oleh karena itu pada masa pemerintahan Mataram banyak pemberontak-pemberontak kerajaan Mataram yang membangun basis kekuatan di Madiun. Seperti munculnya tokoh Retno Dumilah. Beberapa peninggalan Kadipaten Madiun salah satunya dapat dilihat di Kelurahan Kuncen, di mana terdapat makam Ki Ageng Panembahan Ronggo Jumeno, Patih Wonosari selain makam para Bupati Madiun, Masjid Tertua di Madiun yaitu Masjid Nur Hidayatullah, artefak-artefak disekeliling masjid, serta sendang (tempat pemandian) keramat.

Kota Madiun dahulu merupakan pusat dari Karesidenan Madiun, yang meliputi wilayah Magetan, Ngawi, Ponorogo, dan Pacitan. Meski berada di wilayah Jawa Timur, secara budaya Madiun lebih dekat ke budaya Jawa Tengahan (Mataraman atau SoloYogya), karena Madiun lama berada di bawah kekuasaan Kesultanan Mataram. Pada tahun 1948, terjadi pemberontakan yang dilakukan oleh PKI di Madiun yang dipimpin oleh Musso di daerah Dungus, Wungu, Kabupaten Madiun yang sekarang di kenal dengan nama Monumen Kresek.

\section{METODE PENGABDIAN}

1. Analisis Situasi Masyarakat.

Merupakan tahap awal yang sangat penting sebab memang kegiatan pengabdian pada masyarakat harus dari niat untuk membantu masyarakat. Menganalisis situasi masyarakat juga berguna untuk melihat apa kekurangan dan apa yang dibutuhkan oleh masyarakat. Sehingga sasaran bisa tertuju dengan tepat.

2. Identifikasi Masalah.

Hasil dari analisis situasi kemudian dapat ditemukan dan dirumuskan permasalahan yang dialami dan dihadapi masyarakat.

3. Menentukan Tujuan Kerja.

Pada tahap ini harus dapat ditentukan kondisi baru apa yang dihasilkan dari pengabdian nantinya. 
4. Rencana Pemecahan Masalah.

Masalah yang sudah diidentifikasi perlu dipecahkan dan sekaligus mencapai tujuan yang telah ditetapkan. Semua itu perlu direncanakan pada tahap ini.

5. Pendekatan Social.

Adalah pendekatan terhadap masyarakat sebagai sasaran. Prinsipnya ialah bahwa masyarakat sasaran harus dijadikan subjek dan bukan objek dari kegiatan pengabdian masyarakat ini. Untuk itu masyarakat harus sebanyak mungkin dan dilibatkan dalam kegiatan.

6. Pelaksanaan Kegiatan.

7. Evaluasi Kegiatan dan Hasil.

Setiap tahapan memang perlu di evaluasi sehingga timbul keyakinan bahwa segala yang sudah dilakukan dan diputuskan adalah benar dan tuntas.

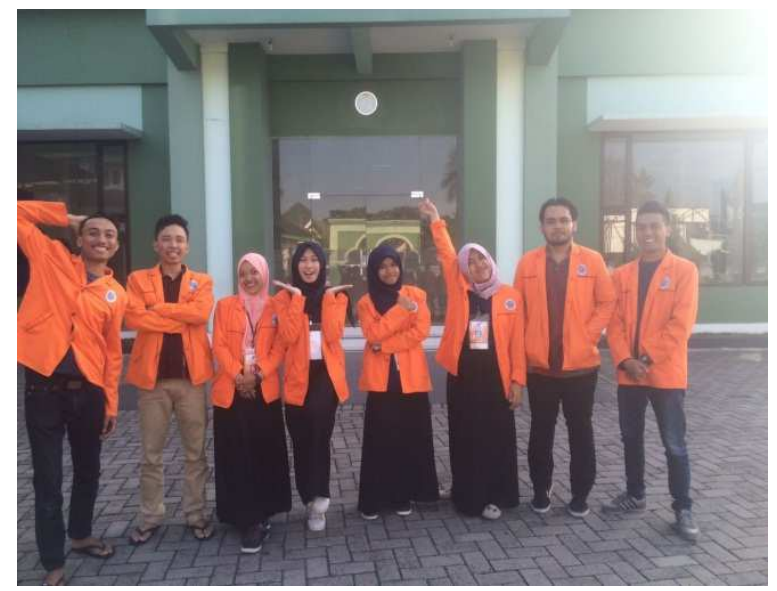

\section{PEMBAHASAN}

Pelaksanaan kegiatan Kuliah Kerja Nyata PPuN di PDM Kota Madiun dimulai penerjunan pada tanggal 30 Juli 2017 di PDM Kota Madiun. Pada hari itu sambutan dilakukan oleh perwakilan-perwakilan PDM Kota Madiun dengan sangat hangat. Karena tidak adanya survey yang dilakukan sebelum KKN. Maka yang kami lakukan terlebih dahulu adalah observasi ke amal usaha Muhammadiyah antara lain sekolah dan panti asuhan. Maka dari itu dalam satu bulan, kegiatan kami banyak dilakukan di panti asuhan Muhammadiyah, sekolah Muhammadiyah, dan sekolah tinggi Muhammadiyah. Namun itulah yang membuat kami nyaman dan kerasan di Maidun. Hari demi hari kami lalui dengan sangat baik. Ada beberapa acara pokok yang saat itu kami laksanakan dalam waktu satu bulan. Diantaranya pelatihan seni, branding sekolah dan pecan seni pelajar Muhammadiyah se-ekskarisidenan Madiun. Pemateri dari acara-acara pokok tersebut juga sudah berkompeten dibidangnya masing-masing.

Acara pertama adalah pelatihan seni yang meliputi pelatihan mendongeng, musikalisasi puisi, festival masjid dan pelatihan gerak dan lagu yang diperuntutkan bagi guru-guru sekolah Muhammadiyah yang meliputi TK/PAUD, SD, SMP dan SMA. Pelatihan seni tersebut bertujuan untuk memperbaiki beberapa pembelajaran yang mulai saat ini sudah jauh dari kaidah-kaidah keIslaman dan membahayakan moral generasi 
penerus bangsa. Tujuan berikutnya adalah langkah pertama sebelum ke acara pecan seni pelajar Muhammadiyah yang tentunya akan diikuti oleh sekolah-sekolah yang gurunya sudah mengikuti pelatihan seni tersebut.

Acara yang kedua adalah branding sekolah Muhammadiyah. Branding ini bertujuan untuk mengolah dan membuat sekolah-sekolah Muhammadiyah di Kota Madiun lebih menarik dan mempunyai daya saing terhadap sekolah negeri di Kota Madiun. Acara branding tersebut juga diikuti oleh sekolah Muhammadiyah yang meliputi TK/PAUD, SD, SMP dan SMA.

Acara yang ketiga atau acara utama adalah festival seni pelajar se-ekskresidenan Madiun yang meliputi Kota Ngawi, Magetan, Ponorogo, Kabupaten Madiun. Persiapan sudah dilakukan jauh-jauh hari, antara lain menghubungi sekolah-sekolah yang akan menjadi peserta lomba. Acara ini adalah hasil dari pelatihan seni yang sudah terlaksana. Para peserta cukup antusias dalam mengikuti pekan seni pelajar tersebut. Acara berjalan dengan lancar sejak awal hingga akhir. Rangkaian acara-acara tersebutlah yang disebut dengan pembelajaran dan pemberdayaan masyarakat tentunya guru-guru sekolah Muhammadiyah di Madiun yang akan memberikan hasil pembelajaran bagi murid dan sekolahnya masing-masing.

\section{E. KESIMPULAN}

Kuliah Kerja Nyata (KKN) adalah bentuk kegiatan pengabdian kepada masyarakat oleh mahasiswa dengan pendekatan lintas keilmuan dan sektoral pada waktu dan daerah tertentu. Mahasiswa diharapkan dapat mengembangkan pemikiran berdasarkan ilmu tekhnologi dan dalam upaya menumbuhkan, mempercepat serta mempersiapkan kaderkader pembangunan. Mahasiswa memperoleh pengalaman belajar yang berharga melalui keterlibatan dalam masyarakat yang secara langsung menemukan, merumuskan, memecahkan dan menanggulangi permasalahan pembangunan secara prakmatis dan interdisipliner. Terlebih dalam KKN PPuN ini, Mahasiswa diharapkan dapat menjadi pembelajar dan pemberdaya dalam masyarakat dengan program-program yang

\section{F. SARAN}

Dalam waktu sebulan, memang sangat singkat dan cepat, ditambah tidak adanya survey semakin membuat KKN PpuN ini penuh dengan tantangan. Namun dengan usaha keras dan kerjasama yang bagus, alhamdulillah semua itu dapat kami hadapi. Untuk kedepan mungkin bisa disiapkan lagi supaya lebih bagus, persiapan tersebut meliputi survey, koordinasi dengan PDM, dan warga terdekat setempat supaya kegiatan-kegiatan inti tersebut dapat berjalan dengan lancar dan diimbangi dengan antusias dari pesertapeserta kegiatan.

\section{DAFTAR PUSTAKA}


